\title{
REFORMULASI KEWENANGAN MPR PASCA AMANDEMEN UUD NRI 1945
}

Oleh:

\author{
Dr. Dwi Haryadi, S.H., M.H.*
}

\begin{abstract}
People's consultative assembly (MPR) from the beginning is formed as an institution with consensus principle, a principle of people's consultative through consultative agency. The position and the authority of consultative agency started to change significantly after the amandements of 1945's constitution. Even some opined that people's consultative assembly is no longer required. There are several important issues that will be discuss as the main topic in this paper. First, development planning vs broad outlines of the nations direction (GBHN). Second, the authority of people's consultative assembly to set the regulating provisions. Third, the authority of people's consultative assembly to provide a constitutional interpretation. Fourth, this assembly reviewed it's own provisions. Fifth, this assembly issued a decree inaugurating of president and vice president. These fifth reformulation issues are crucial among the dynamics of our state administration system and our current conditions, also in order to strengthen the functions of the people's consultative assembly as a center for people's representation.
\end{abstract}

Keywords: People's Consultative Assembly (MPR(, Reformulation, Authority.

\section{A. PENDAHULUAN}

Keberadaan

Majelis

Permusyawaratan Rakyat (MPR)

merupakan wujud dari prinsip ketiga

yang disampaikan Soekarno pada 1

Juni 1945, yaitu prinsip mufakat,

prinsip perwakilan rakyat melalui

Badan Perwakilan ${ }^{1}$ Soekarno

menyadari bahwa demokrasi

Indonesia yang tepat adalah

pemusyawaratan dan perwakilan.

*Dosen Tetap Fakultas Hukum Universitas Bangka Belitung

1 Soekarno, Lahirnya Pancasila "Pidato di Depan Dokuritsu Zyunbi Tyoosakai 1 Juni 1945, Yayasan Tritunggal, Semarang, 1999. hlm. 37.
Secara historis, kehadiran MPR memang menjadi kekhasan Indonesia, karena kelima lembaga negara lain merupakan cetak biru yang dicontoh dari zaman Hindia Belanda, yaitu Dewan Perwakilan Rakyat (DPR), Presiden, Mahkamah Agung (MA), Badan Pemeriksa Keuangan (BPK) dan Dewan Pertimbangan Agung (DPA). DPR terkait dengan Volksraad (Dewan Rakyat), Presiden pengganti dari Gouvernuur Generaal, MA terkait dengan Landraad dan Raad van Justitie, BPK dengan Raad van 
Rekenkamer dan DPA berasal dari Raad van State Nederlandshce Indie ${ }^{2}$.

MPR yang diharapkan sebagai penjelmaan seluruh rakyat, menurut Jimly Asshiddqie sering dipersoalkan dan diperdebatkan sejauh mana eksistensinya sebagai sebuah lembaga (institusi) atau sekedar forum majelis belaka. Padahal jika melihat perbandingan di negara lain, seperti Belanda dan Amerika Serikat juga menganut yang sama ${ }^{3}$.

Di bawah ini perbandingan kedudukan, keanggotaan dan kewenangan MPR sebelum dan sesudah amandemen:

\begin{tabular}{|c|c|c|}
\hline Pasal & $\begin{array}{c}\text { Sebelum } \\
\text { Amandemen }\end{array}$ & $\begin{array}{c}\text { Sesudah } \\
\text { Amandemen }\end{array}$ \\
\hline $\begin{array}{c}1 \\
\text { Ayat } \\
2\end{array}$ & $\begin{array}{l}\text { Kedaulatan } \\
\text { adalah di } \\
\text { tangan rakyat, } \\
\text { dan } \\
\text { dilakukan } \\
\text { sepenuhnya } \\
\text { oleh MPR }\end{array}$ & $\begin{array}{l}\text { Kedaulatan berada } \\
\text { di tangan rakyat } \\
\text { dan dilaksanakan } \\
\text { menurut UUD }\end{array}$ \\
\hline $\begin{array}{c}2 \\
\text { Ayat } \\
1\end{array}$ & $\begin{array}{l}\text { MPR terdiri } \\
\text { atas anggota- } \\
\text { anggota } \\
\text { DPR, } \\
\text { ditambah } \\
\text { utusan- } \\
\text { utusan dari } \\
\text { daerah dan } \\
\text { golongan- } \\
\text { golongan, }\end{array}$ & $\begin{array}{l}\text { MPR terdiri atas } \\
\text { anggota } \boldsymbol{D P R} \text { dan } \\
\text { anggota } \mathbf{D P D}\end{array}$ \\
\hline 3 & $\begin{array}{l}\mathrm{MPR} \\
\text { menetapkan } \\
\text { UUD dan } \\
\text { GBHN }\end{array}$ & $\begin{array}{ll}\text { (1) } & \text { MPR } \\
& \text { berwenang } \\
& \text { mengubah } \\
& \text { dan } \\
& \text { menetapkan } \\
& \text { UUD } \\
\text { (2) } & \text { melantik }\end{array}$ \\
\hline
\end{tabular}

2 Jimly Asshiddiqie, Konstitusi dan Konstitusionalisme Indonesia, Sekjend MK, Jakarta, 2006. hlm. 167-168.

${ }^{3}$ Ibid., hlm. 173-174.

\begin{tabular}{|c|c|c|c|}
\hline & & (3) & $\begin{array}{l}\text { Presiden } \\
\text { dan/atau } \\
\text { Wapres } \\
\text { dapat } \\
\text { memberhenti } \\
\text { kan Presiden } \\
\text { dan/atau } \\
\text { Wapres } \\
\text { dalam masa } \\
\text { jabatannya }\end{array}$ \\
\hline 8 & $\begin{array}{l}\text { Jika Presiden } \\
\text { mangkat, } \\
\text { berhenti, atau } \\
\text { tidak dapat } \\
\text { melakukan } \\
\text { kewajibannya } \\
\text { dalam masa } \\
\text { jabatannya, ia } \\
\text { diganti oleh } \\
\text { Wapres } \\
\text { sampai habis } \\
\text { waktunya }\end{array}$ & $\begin{array}{l}\text { (1) } \\
\text { (2) }\end{array}$ & $\begin{array}{l}\text { Jika Presiden } \\
\text { mangkat, } \\
\text { berhenti, } \\
\text { diberhentika } \\
\text { n, atau tidak } \\
\text { dapat } \\
\text { melakukan } \\
\text { kewajibannya } \\
\text { dalam masa } \\
\text { jabatannya, ia } \\
\text { digantikan } \\
\text { oleh Wapres } \\
\text { Jika } \\
\text { kekosongan } \\
\text { Wapres, } \\
\text { MPR mengelenggar } \\
\text { menye sidang } \\
\text { akan } \\
\text { untuk } \\
\text { memilih } \\
\text { Wapres dari } 2 \\
\text { calon yang } \\
\text { diusulkan } \\
\text { oleh Presiden. } \\
\text { Presiden dan } \\
\text { Wapres } \\
\text { kosong } \\
\text { bersamaan, } \\
\text { MPR memilih } 2 \\
\text { pasangan } \\
\text { calon yang } \\
\text { diusulkan } \\
\text { oleh parpol/gabun } \\
\text { gan parpol } \\
\text { peraih suara } \\
\text { terbanyak } \\
\text { pertama dan } \\
\text { kedua }\end{array}$ \\
\hline
\end{tabular}

Berdasarkan tabel di atas, terlihat amandemen terkait MPR mengandung beberapa hal, seperti kedudukannya tidak lagi sebagai lembaga tertinggi dan bukan sebagai representasi 
kedaulatan rakyat, keanggotaan terdiri atas anggota DPR dan anggota DPD, tidak lagi menetapkan GBHN, dan penambahan Pasal 8 sebagai untuk mencegah persoalan ketatanegaraan jika memang kondisi tersebut terjadi, seperti presiden dan wapres berhenti secara bersamaan.

\section{B. PEMBAHASAN}

1. Sistem

Perencanaan

Pembangunan Nasional Versi GBHN

Salah satu kewenangan MPR dalam menetapkan Garis-Garis Besar Haluan Negara $(\mathrm{GBHN})^{4}$ dihilangkan. Padahal sebelum reformasi, GBHN sebagai produk politik MPR menjadi acuan pokok dalam perencanaan dan pelaksanaan pembangunan nasional yang wajib dijalankan oleh Pemerintah. Hal ini sejalan dengan posisi Presiden sebagai mandataris $\mathrm{MPR}^{5}$.

Pengalaman 3 (tiga) periode pemerintahan pasca munculnya Sistem Perencanaan Pembangunan

\footnotetext{
${ }^{4}$ Pasal 3 UUD 1945 sebelum amandemen "MPR menetapkan UUD dan garis-garis besar daripada haluan negara”. Di era Presiden Soekarno bukan mengggunakan istilah GBHN tetapi "Pembangunan Semesta Berencana"

${ }^{5}$ Pasal 6 ayat (2) UUD 1945 sebelum amandemen "Presiden dan Wakil Presiden dipilih oleh MPR dengan suara yang terbanyak”.
}

Nasional/SPPN (sebagai pengganti GBHN) tahun 2004, yaitu periode SBY-JK, SBY-Boediono dan saat ini Jokowi-JK, beberapa pihak ${ }^{6}$ menilai pembangunan tidak terarah, sehingga penting menghidupkan kembali GBHN. Beberapa pendapat muncul terkait implementasi SPPN yang dinilai mengandung beberapa persoalan. Pertama, RPJMN yang dibuat lima tahun tidak konsisten dan tidak berkesinambungan dengan RPJPN. Kedua, perencanaan pembangunan dan pelaksanaan RPJMN dimonopoli dan berorientasi pada kepentingan eksekutif saja. Ketiga, RPJMD provinsi dan kabupaten/kota tidak sinkron dengan RPJMN, karena dibuat dengan prespektif lokal dan

${ }^{6}$ Kaelan : Secara politis RPJMN merupakan produk Presiden dan dilaksanakannya sendiri tanpa ada sanksi yuridis jika terjadi penyimpangan maupun gagal mencapai target; Sofian Effendi : Penghapusan GBHN harus dikoreksi kembali, dibutuhkan kesinambungan pembangunan; Yudi Latief : GBHN karya otentik pendiri bangsa dan bukan rekayasa orde baru. RPJMN itu kepentingan Presiden, sedangkan GBHN untuk kepentingan rakyat dan negara; Sidarto Danusubroto : Kembalikan GBHN melalui amandemen UUD, karena RPJP tidak dapat berkesinambungan dengan RPJMN yang berubah setiap ganti Presiden; Irman Gusman : Setuju menghidupkan kembali GBHN, namun tak perlu MPR sebagai lembaga tertinggi negara; Wiranto : RPJP tidak adil karena dibuat, dikontrol dan dinilai oleh pemerintah sendiri. 
perbedaan waktu penyelenggaraan

Pilpres dan Pilkada yang beragam.

Penting mengutip pernyataan

Saldi Isra, "meski dengan sesadarsadarnya kita memerlukan arah pembangunan nasional, membayangkan GBHN dengan pola MPR sebelum perubahan UUD 1945 tentu tidak begitu tepat lagi. Langkah awal yang harus dilakukan adalah mencari sebab utama arah pembangunan yang semakin tidak terpadu. Misalnya bagaimana melihat ketersambungan antara rencana yang disusun Bappenas, penyusunan RAPBN di Kemenkeu dan pembahasan RAPBN di DPR". 7

Menurut penulis, ide tentang SPPN rasa GBHN dapat diterjemahkan melalui beberapa pokok pikiran sebagai berikut:

a. MPR perlu diberikan kewenangan untuk terlibat dalam penyusunan SPPN (RPJPN dan RPJMN) bersama pemerintah untuk menghindari perencanaan pembangunan yang hanya berorientasi pada kepentingan eksekutif semata, serta dalam rangka menjamin RPJMN disusun tidak hanya

7 Saldi Isra, Wacana Menghidupkan GBHN, Kompas 12 Januari 2016 terjemahan visi misi presiden tetapi juga wajib sejalan dengan visi RPJPN dan setiap tahapan RPJMN. Konsekuensinya, apabila MPR terlibat, maka harus dilakukan amandemen terkait penambahan kewenangan baru MPR dan pelibatan DPD RI yang selama ini kewenangan legislasinya terbatas.

b. Produk hukum untuk GBHN kekinian yang paling memungkinkan dan konstitusional adalah dalam bentuk Undang-Undang yang dirumuskan oleh Pemerintah, DPR dan DPD.

2. Kewenangan MPR dalam Menetapkan Ketetapan Bersifat Mengatur

Pasca amandemen, MPR dapat mengeluarkan putusan majelis dalam 3 jenis, yaitu perubahan dan penetapan UUD, Ketetapan dan Keputusan. Ketetapan MPR itu berisi yang bersifat penetapan (beschikking), yang kekuatan mengikatnya ke dalam dan ke luar. Muncul pertanyaan, apakah mungkin MPR dapat mengeluarkan ketetapan yang bersifat mengatur (regelling)? Berdasarkan kewenangan MPR yang diberikan 
oleh konstitusi, jelas bahwa MPR tidak lagi berwenang menetapkan GBHN. Artinya MPR hanya berwenang untuk menerbitkan aturan dasar negara hanyalah sebatas UUD.

Mengutip pendapat Satjipto Rahardjo ${ }^{8}$, bahwa regelling itu sifatnya berlaku umum, tidak kongkrit, dan ditujukan untuk publik. Sementara beschikking bersifat kongkrit, individual dan berlaku sekali waktu (enmalig). Menurut Mahfud $\mathrm{MD}^{9}$, Ketetapan MPR tetap ada tetapi terbatas hanya untuk penetapan yang bersifat beschikking (konkrit dan individual), misalnya ketetapan pengangkatan Presiden. Bahkan menurutnya Ketetapan MPR dapat dijadikan sebagai sumber hukum materiil, bukan formal (perundangundangan). Kemudian pada tahun 2003 pernah dinyatakan oleh MPR bahwa aturan yang mengikat publik diimplementasikan melalui UU. Di samping itu harus disadari bahwa kehadiran MPR merupakan joint session antara DPR dan DPD yang baru bekerja sesuai dengan perintah

8 Satjipto Raharjo, Ilmu Hukum, Citra Aditya, Bandung, Cet VII, 2012, hlm 83-84.

9 Mahfud MD, Perdebatan Hukum Tata Negara Pasca Amandemen Konstitusi, Rajawali Pers. Jakarta, 2010, hlm. 32.
UUD. Menurut Jimly Asshidiqie ${ }^{10}$, MPR dikatakan ada (actual existence) disaat menjalankan kewenangannya.

\section{Kewenangan MPR untuk}

\section{Memberikan Tafsir Konstitusi}

Tafsir konstitusi berdasarkan isi konstitusi itu sendiri dapat dilakukan oleh MPR dan Mahkamah Konstitusi. MPR melalui kewenangannya merubah dan menetapkan UUD. Sementara Mahkamah Konstitusi melalui judicial review yang diajukan kepadanya. Terkait adanya usulan untuk MPR dapat memberikan tafsir konstitusi dalam penguji UU terhadap UUD oleh MK bisa saja dilakukan, tetapi atas permintaan MK, bukan pemohon maupun termohon. Disini posisi MPR harus netral sebagai penjaga konstitusi. Terkait netralitas ini sangat penting dipikirkan, termasuk mekanisme siapa yang akan mewakili MPR untuk memberikan tafsir. Mengingat MPR adalah kombinasi antara DPR dan DPD. Penting diketahui bahwa DPR dan DPD merupakan pihak-pihak terkait

10 Jimly Asshidiqie, Sengketa Kewenangan Konstitusional Lembaga Negara, Konstitusi Pers, Jakarta, 2006., hlm. 87. 
yang dapat dimintai keterangan oleh MK sehubungan dengan UU yang digugat, karena posisinya sebagai legislator dan colegislator. $^{11}$

Namun sebelum jauh kesana, sebenarnya penting untuk dikemukakan terlebih dahulu urgensi kehadiran MPR untuk memberikan tafsir konstitusi apa, mengapa dan siapa?

\section{MPR Mereview Ketetapannya}

Kewenangan MPR untuk melakukan peninjauan terhadap materi dan status hukum ketetapan MPR No. I/MPR/2003 tentang Peninjauan terhadap materi dan status hukum Ketetapan MPRS dan Ketetapan MPR tahun 1960 sampai dengan tahun 2002, pada dasarnya merupakan bentuk pelaksanaan perintah dari Aturan Tambahan Pasal I UUD 1945. Paling tidak ada 139 Ketetapan MPRS dan MPR yang masih berlaku dan direview. Ada beberapa alasan kenapa review ini harus dilakukan:
a. Menghindari adanya ketidakpastian hukum pasca amandemen

\footnotetext{
11 Jimly Asshidiqie, Hukum Acara Pengujian Undang-Undang, Sekjend MK, Jakarta, 2005. hlm. 172-176.
}

b. Adaptasi perubahan istilah dan harmonisasi adanya perubahan kedudukan, kewenangan, fungsi dari setiap lembaga negara

c. Identifikasi status hukum, individual-umum, konkritabstrak, dan final-terus menerus. Berdasarkan alasan-alasan tersebut, tentu tidak ada persoalan kewenangan ini dilakukan. Di samping konstitusional, juga memberikan kepastian hukum dan tidak "boros aturan". Harmonisasi dengan UUD pasca amandemen tentunya harus menyeluruh, termasuk juga Ketetapan MPRS dan MPR yang berlaku sebelumnya. Hasil dari review tersebut jelas bahwa dari 139 Ketetapan MPRS dan MPR hanya 13 yang berlaku, dan 126 tidak berlaku lagi. Ada 3 ketetapan yang dinyatakan tetap berlaku dengan ketentuan, dan 10 ketetapan dinyatakan tetap berlaku sampai dengan terbentuknya UU.

\section{MPR mengeluarkan Ketetapan} tentang Pelantikan Presiden dan Wakil Presiden

$$
\begin{aligned}
& \text { Salah satu kewenangan MPR } \\
& \text { yang diberikan UUD adalah } \\
& \text { melantik Presiden dan/atau Wakil } \\
& \text { Presiden. Secara eksplisit }
\end{aligned}
$$


disebutkan hanya "melantik". Apakah melantik disini termasuk juga didalamnya? Menurut kami ketentuan konstitusi sudah jelas bahwa hanya sebatas melantik, dan ini sejalan juga dengan UU Pemilu. Secara hukum formal ketatanegaraa tentu tidak ada persoalan dengan MPR mengeluarkan ketetapan yang bersifat penetapan. Namun secara substansi/materi yang diatur, yaitu penetapan menurut penulis bertentangan dengan ketentuan konstitusi bahwa Presiden dan Wapres merupakan hasil pilihan rakyat secara langsung dan dipilih oleh MPR. Konsekuensi dari pemilihan langsung tersebut dan kedaulatan ada ditangan rakyat, maka jelas disebutkan bahwa MPR hanya melantik. Meskipun ada yang berpandangan bahwa inikan hanya sebatas membuat ketetapan. Namun dapat menimbulkan multitafsir. Misalnya, presiden dan wapres terpilih belum dapat dilantik sebelum ada penetapan oleh MPR. Akhirnya kepentingan politik disini akan cenderung menonjol. Belum lagi terkait dengan prasyarat penetapan yang harus qorum misalnya. Bagaimana jika separuh MPR dikuasai oleh partai pendukung partai calon presiden yang kalah.

Hal yang berbeda jika presiden dan wapres yang akan ditetapkan bukan hasil pemilihan langsung tetapi karena faktor presiden atau wapres wafat dan lain-lain sehingga harus memilih presiden dan/atau wapres sebagaimana diatur dalam UUD. Hal ini sudah pernah terjadi pada saat dikeluarkannya TAP MPR No. III/MPR/2001 tentang Penetapan Wakil Presiden Megawati Soekarno Putri sebagai Presiden Republik Indonesia. Hal ini dapat diterima karena memang bukan hasil pemilihan langsung dan memang pada saat itu amandemen UUD belum selesai dilakukan dan masih berlaku yang lama. Dimana presiden masih dipilih oleh MPR.

\section{DAFTAR PUSTAKA}

Jimly Asshidiqie, 2005, Hukum Acara Pengujian Undang-Undang, Sekretariat Jenderal Mahkamah Konstitusi, Jakarta.

\section{----------------, 2006, Sengketa Kewenangan Konstitusional Lembaga Negara, Konstitusi Pers, Jakarta. \\ 2006, Konstitusi dan Konstitusionalisme Indonesia, Sekjend MK, Jakarta.}

Mahfud MD, 2010, Perdebatan Hukum Tata Negara Pasca 
Amandemen Konstitusi, Rajawali Pers. Jakarta.

Saldi Isra, Wacana Menghidupkan GBHN, Kompas 12 Januari 2016

Satjipto Raharjo, 2012, Ilmu Hukum (Cetakan VII), Citra Aditya, Bandung.

Soekarno, 1999, Lahirnya Pancasila "Pidato di Depan Dokuritsu Zyunbi Tyoosakai 1 Juni 1945, Yayasan Tritunggal, Semarang. 